\title{
Poultry production in Nigeria: exploiting its potentials for rural youth empowerment and entrepreneurship
}

${ }^{1}$ Ajala, A. O., ${ }^{2}$ Ogunjimi, S. I., ${ }^{3}$ Famuwagun, O. S. and ${ }^{1}$ Adebimpe, A. T.

${ }^{1}$ Department of Agricultural Economics and Extension, Landmark University, Omu-Aran, Kwara State, Nigeria.

${ }^{2}$ Department of Agricultural Economics and Extension, Federal University, Oye- Ekiti, Nigeria.

${ }^{3}$ HG Analytics, Thatcham, UK

Corresponding author: ajala.abiodun@lmu.edu.ng; abiodunajala66@yahoo.com; 07068617924

Abstract

Sustainable rural development cannot occur without rural youth empowerment for entrepreneurship. In the face of the current staggering level of youth unemployment in Nigeria, there is the obvious need to seek for ways of empowering the youth for sustainable development. Poultry keeping stands as resource that can generate employment for millions of Nigerian youths in rural and peri-urban areas as entrepreneurs, skilled and unskilled workers. This paper through a review of literature examined the importance of poultry and explored how it can be exploited as a panacea for youth unemployment through entrepreneurship. It explores the potentials of it and shows the way the potentials of poultry can be harnessed for all youth empowerment programmes. It recommended that government, big farms, international and national corporations, should be involved in youth empowerment programmes through youth entrepreneurship in poultry production. Banks and other financial institutions should be mandated to assist the youth with soft loans in cash and kind through the provision of poultry infrastructure so as to make poultry farming attractive to the youth. A well-funded poultry extension advisory service need to be established to ensure the sustainability of the youth empowerment/ entrepreneurship poultry programmes across the country.

Keywords: Entrepreneurship, Poultry, empowerment, unemployment

\section{La Production avicole au Nigéria: exploiter ses potentiels pour l'autonomisation et l'esprit d'entreprise des jeunes ruraux}

\section{Résumé}

Le développement rural durable ne peut que se faire sans l'autonomisation des jeunes ruraux pour l'esprit d'entreprise. Face au niveau actuel stupéfiant de chômage des jeunes au Nigéria, il est évident qu'il est nécessaire de chercher des moyens d'autonomiser les jeunes pour le développement durable. L'élevage de volailles est une ressource qui peut générer des emplois pour des millions de jeunes Nigérians dans les zones rurales et périurbaines en tant qu'entrepreneurs, travailleurs qualifiés et non qualifiés. Cet article, à travers un examen de la littérature, a examiné l'importance de la volaille et exploré comment elle peut être exploitée comme panacée pour le chômage des jeunes par l'entrepreneuriat. Il explore les potentiels de celui-ci et montre comment les potentiels de la volaille peuvent être exploités pour tous les programmes d'autonomisation des jeunes. Il a recommandé que le gouvernement, les grandes exploitations agricoles, les entreprises internationales et 
nationales participent à des programmes d'autonomisation des jeunes par l'entrepreneuriat des jeunes dans la production avicole. Les banques et autres institutions financières devraient avoir pour mandat d'aider les jeunes avec des prêts à taux doux en espèces et en nature par la fourniture d'infrastructures avicoles afin de rendre l'élevage avicole attrayant pour les jeunes. Un service consultatif bien financé de vulgarisation de la volaille doit être mis en place pour assurer la durabilité des programmes d'autonomisation des jeunes et d'entrepreneuriat de la volaille dans tout le pays.

Mots clés: L'autonomisation, l'esprit d'entreprise, chômage, L'élevage de volailles

\section{Introduction}

The domestication of birds such as chicken, ducks, quails, turkey, and geese with the intent of rearing them for meat, egg production as well as using their products such as faecal droppings and feathers in industries as natural unprocessed materials is known as poultry farming (Stiles, 2017). The rearing of birds originated many years ago, which emanated by collection of their eggs and young ones from their natural habitat which later resulted into domesticating them as farm animals with people. Cockfighting was initiated through rearing of chickens as well as taming of quails for their songs but were later ensnared and brought up as reared birds for consumption (Chakraborty and Chakrabarty, 2017; Chakraborty, 2018). Poultry production can be subdivided into three distinct parts named small, medium and large scale (Heise, Crisan and Theuvsen, 2015). These are also otherwise known as backyard, semi-commercial and commercial (Omiti and Okute, n.d.; Ricke, 2017; Rimi, et al., 2017). The country's standing poultry population is at present 180 million birds, a substantial increase from about 151 million birds (Onwualu, 2011; FAO, 2018) most of which are domiciled in the southern part of the country either in semi-intensive farms or intensive ones (FAO, 2018). Egg and meat production are the two major divisions of poultry production (United States Department of Agriculture - USDA, 2018) although other divisions exist such as chick production, point of lay production, feed production, poultry tools and equipment production in addition to poultry processing and marketing (Compassion in World Farming - CIWF, 2019). Although globally, as at 2011 and 2016, over 50 billion poultry birds and 66 billion poultry birds were produced across the world respectively (Foraminifera, 2012; Qualman, 2018); these numbers had dropped to 23 billion birds by 2018 due to the more recent outbreak of avian influenza (H5N1 and mutated strains) in China which affected $13.6 \%$ of the world's poultry supply during the year 2016 in addition to the effect of ongoing poultry consumption by the human population (Chatziprodromidou, et al., 2018). The nutritional benefits derived from poultry products such as animal protein, minerals, fat-soluble vitamins, carbohydrates, pigments, fluids, and cholesterol is attributable to its relevance as the world major source of food (Dilger, Schroeder and Moseley, 2016). Most poultry houses in rural settlements of the country are substandard and handled by less competent farm operators who are not favourably disposed to using relevant or new approaches to managing poultry production efficiently and thus affecting poultry yield adversely (FAO, 2018). This constituted the major reason why European countries have usually had a higher yield in their poultry production and consumption than less developed countriesacross the world especially Africa and Asia (AugèreGranier, 2019; Ritchie and Roser, 2019). 


\section{Ajala, Ogunjimi, Famuwagun and Adebimpe}

Other reasons include climate change, ineffective resource management and inadequate provision of capital and operating credit (Science Communication Unit, University of the West of England, Bristol, 2013; Rojas-Downing, et al., 2017; Ricke, 2017). It has been estimated that by 2030, the demand for poultry products across the African continent will increase by $60 \%$ especially in Nigeria, its largest market (World Economic Forum, 2019). Currently, present consumption across the continent is almost 100 million tonnes respectively for both poultry meat and egg products while in Nigeria, 192.69 MT is consumed annually (Ritchie and Roser, 2019). A society where adults and younger ones are inspired to take charge of how they live their lives is known to exhibit youth empowerment (Ile and Boadu, 2018; United Nations Development ProgrammeUNDP, 2020). These set of people are known totake concrete steps that will enhance their access to available resources which would improve their values, beliefs and attitudes as well as their standard of living (Ile and Boadu, 2018). Youth empowerment can be actively enhanced by engaging the adults in youth empowerment programmes which aims at enhancing their standard of living (Dominique and Dominique, 2014). Poultry business has been the most demanding section of animal rearing as regards farm products in Nigeria which offers great potentials for sustainable development in youth empowerment programmes (Ajani, Mgnbenka, and Onah, 2015; Price, 2019). Consequently, literatures reviewed showed that $0.2 \%$ of Nigeria's aggregate meat demand is met by the poultry industry while the rest is supplied by such segments of the livestock market such as cattle production, rabbitry, and grasscuttery. This revealed a wide deficient gap in comparison to that of European countries which is characterised by large supply infrastructures and abilities
(World Economic Forum, 2019). The aforementioned is as a result of Nigeria's poultry production industry which has its own share of challenges. These challenges stem from exorbitant price of raw materials used for animal feed production; although, this issue is a general concern in every part of the world (Ahmed and Mohammed, 2015; Heise, Crisan and Theuvsen, 2015). This challenge is further accentuated by the following: inadequate local production of corn, soya and chicks; inadequate number of youths who are the actively growing population involved in the poultry production business; poorly funded and staffed existing or moribund extension services to train and give advisory services to youths engaged in poultry production and the scourge of diseases and pests (Heise, Crisan and Theuvsen, 2015). Others are poor infrastructure such as roads which hinder the easy movement of trucks which carry the feed and other inputs to the farms located in remote rural areas where the poultry farms are located for effective distribution of inputs and for taking the stock produced to market; poorly coordinated marketing channels; unsupported insurance policy by the government; delayed allocation of land; poor utilization of economies of scale as majority of poultry in Nigeria is still in the hands of small scale operators; existence of varying degrees of technology because the size of farms vary from small- to largescale (Adeyonu, et al., 2016; Butler, 2016; Derbe and Nachimuthu, 2016; World Economic Forum, 2019).

As at 2018, the annual poultry meat consumption of four important African economies including Nigeria was 176,287.266 MT (Nigeria), 1.1 million MT (Egypt), 10,922.46 MT (Ethiopia), and 1.95 million MT (South Africa) - Organisation for Economic Cooperation and Development, OECD (2019) and World Bank, WB (2020) which is quite moderate 
in the light of Ritchie and Roser (2019) report that Nigeria consumed 192,689 MT, Egypt (1.2 million MT), Ethiopia (73,931 MT) and South Africa (1.76 million MT) during the same period. However, whichever is used, Nigeria still has a long way to go although production and consumption levels have been increasing prior to the period. This means that opportunities still abound for increased and improved production and consumption of poultry products in the country and the youth have a great part to play in it since they are the largest demographic segment of the country at present and they are agile, strong and more healthy than the now aging current population of poultry farmer in the country.

\section{Importance of poultry and poultry products}

The industry also provides raw materials to some industries as well as serve as a take up industry for other industries such as animal health industries (Omiti and Okuthe, n.d.). Furthermore, according to Darre (n.d.), the poultry industry also provides economic support and development effect on the tourism sector as well as the fashion industries. Specifically, however, the poultry industry is relevant to human lives and human living as follows: food provision in the form of the supply of protein, vitamins, minerals, and oils; industrial uses such as in the production of vaccines, fertilizers and animal foods. Furthermore, the hospitality industry relies on it for the supply of feathers for display and comfortable luxury mattresses, pillows and cushions as well as in the agricultural industry in the production of organic fertilisers. Lastly, it provides affordable meat for the nation's populace especially those in urban areas (Wahyono and Utami, 2018).

Aspects of the poultry industry relevant for youth empowerment

The aspects of the poultry industry relevant to youth empowerment due to their ease of commencement and availability of factors of production includes Broiler Farming which involves the production of fast growing bird breeds (4 - 7 weeks) for meat consumption using production methods suchas the deep litter system, cage and feed system or the semi-intensive method (Nwandu, et al., 2016); Egg Production which involves raising birds specifically for the sales and supply of eggs using good production practices (Lieshout, Touray and ITC Cosultants, 2017; Nordhagen And Klemm, 2018); Feed formulation, production and sales which involves the production of high quality poultry feeds for local farms based on each farmers requirements and poultry breed needs (Olugbenga, et al., 2015; Swain, 2016; Alhotan, 2016); Sales and Marketing which involves obtaining poultry products such as broiler chicken, eggs, faecal waste, feeds, Day Old Chicken, Point of Lay, etc. from production centres (e.g. mills, farms, and hatcheries) and selling to farmers, retailers and final consumers (Simonič, Dumičić, and Žmuk, 2016); Value Addition which involves the processing of poultry products/by-products into ready to eat or utilize products such as roasted fried chicken, chicken soup, fried/boiled/ scotchedeggs, bread-egg sandwiches, grilled chicken, and chicken barbeques, turkey kielbasa, chicken nuggets, ginger lemon chicken drum sticks, and honey garlic marinated chicken wings (Barbut, 2015); Agrotransportation which involves providing specialized transportation services to poultry farmers including movement of live and processed poultry products between farms and from farms to consumers/retailers (Aldridge, 2019). In summary, the sector is an appropriate sector for the creation of jobs, employment and startups since it has capacity for both Small Number Take-Up and Large Number TakeUps in the country (Wahyono and Utami, 


\section{Ajala, Ogunjimi, Famuwagun and Adebimpe}

2018).

Challenges affecting youth participation in poultry production

According to Njenga, et al, the challenges affecting youth participation in agriculture including poultry production includes poor mindset about the sector, poor access to factors of production, income fluctuation and seasonality, poor infrastructures, the labour-intensitivity of the sector. Other challenges include: development and empowerment politics, problems of tradition, the effect of climate change, poor parental, family and societal view of agriculture generally (although fast changing), use of less effective production methods, and poor government policies (Ajani et al., 2015).

Exploiting the potentials of poultry for youth empowerment-the way forward

The Nigerian government should: incorporate poultry production into its current Agricultural Development Plan at all level (Nwaobialas et al., 2016); poultry production seminars and workshops targeting the youth should be organized regularly ((Dumas et al., 2016) Specialised Youth Entrepreneurial Poultry Financial Support Initiativ, Nnamdi and Ekumankama, 2018); should be introduced where the country's youths can be given loans/grants of up to a million naira for starting and managing their farms successfully (Timi and Adaigho, 2015; Adeyonu et al., 2017; Chioma, 2017); cooperative farms should also be engaged so that the benefits of economies of scale can be adequately utilized and therefore reduce business failure rates. (Heise, Crisan and Theuvsen, 2015; Obasi, 2015); more support should be offered to those who would like to go into poultry value addition and processing (Barbut, 2015); as well as the re-training and continuous training of extension agents in the country on new developments in the sector so as to ensure the success of the initiatives recommended (Olumide-Oyaniyi and Ajayi, 2019).

\section{Conclusion and recommendations}

In conclusion, poultry production has a lot of obvious profitability, employment and empowerment potentials for youths. Therefore it is recommended that various youth empowerment programmes being carried out by government and nongovernmental organisations should incorporate poultry production as a way to achieve sustainable youth empowerment and development. Concerted and sustainable efforts should be made by extension agencies to organize training programmes for youths on improved poultry technologies at cooperative levels. Credit facilities should also be made available to youths in cash and kind.

\section{References}

Adeyonu, A., Ajiboye, B., Isitor S. and Faseyi, S. A. (2017.) An Analysis of the Factors Influencing Access to Credit by Poultry Farmers in Abuja, Nigeria. Available at: https://www.researchgate.net/public ation/327136999_An_Analysis_of t he_Factors_Influencing_Access to Credit by_Poultry_Farmers in A $\bar{b}$ uja Nigeria. Accessed 29th March $20 \overline{20}$.

Adeyonu, A. G., Oyawoye, E. O., Otunaiya, A. O. and Akinlade, R. J. (2016) Determinants of Poultry Farmers' Willingness to Participate in National Agricultural Insurance Scheme in Oyo State, Nigeria. Applied Tropical Agriculture Volume 21, No. 3, 55-62, 2016. https://www.futa.edu.ng/journal/ho me/downloadpdf/paper_3_1508324 827. Accessed on the 15 th March 2020.

Ahmed, E., and Mohammed, B. S. (2015) Impediment Observed in Poultry 
Farming in Kastina State, Northern Nigeria August 2015. International Research Journal of Social Sciences 5(3):153-166.

Ajani, E. N., Mgbenka, R. N., and Onah, O. (2015) Empowerment of Youths in Rural Areas through Agricultural Development Programmes: Implications for Poverty Reduction in Nigeria. International Journal of Research in Agriculture and Forestry Volume 2, Issue 2, February 2015, PP 34-41 ISSN 2394-5915 (Online) Available at: http://ijraf.org/pdf/v2i2/5.pdf. Accessed 15th March 2020.

Alders, R., Costa, R., Gallardo, R. A., Sparks, N., and Zhou, H. (2019) Smallholder Poultry: Leveraging for Sustainable Food and Nutrition Security. Encyclopedia of Food Security and Sustainability Volume 3, 2019, Pages 340-346. Available at: https://doi.org/10.1016/B978-0-08100596-5.21544-8. Accessed 29th March 2020.

Alhotan, R. A. (2016) Strategies To Improve Poultry Feed Formulation For Maximum Performance And Profitability. Available at: https://getd.libs.uga.edu/pdfs/alhota n_rashed_a_201608_phd.pdf. Accessed 29th March 2020.

Augère-Granier, M. (2019) The EU poultry meat and egg sector: Main features, challenges and prospects. In-Depth Analysis. European Parliamentary Research Service. A v a i l a b l e a t : https://www.europarl.europa.eu/Reg Data/etudes/IDAN/2019/644195/EP RS_IDA(2019)644195_EN.pdf. Accessed on the 15th March 2020.

Barbut, S. (2015) The Science of Poultry and Meat Processing. Available at: http://download.poultryandmeatproc essing.com/v01pdf. Accessed 29th March 2020.
Chakraborty, P., and Chakrabarty, F. (2017) Cock Fight: A Symbolic View of Social Status. International Journal of Social Science Citation: IJSS: 6(1): 39-43, March 2017. DOI: 10.5958/2321-5771.2017.00005.9. A v a i 1 a b 1 e a $\mathrm{t}$ : https://ndpublisher.in/admin/issues/I JSSV6N1e.pdf. Accessed on the 15th March 2020.

Chakraborty, P. (2018) Historic cockfight among the Santals: An Anthropological View. Availableat: https://www.researchgate.net/public ation/329773141_Historic_cockfigh t_among the_Santals_An_Anthropo logical view. Accessed on the 15th March $\overline{2} 020$.

Chatziprodromidou, I. P., Arvanitidou, M., Guitian, J., Apostolou, T., Vantarakis, G., and Vantarakis, A. (2018). Global avian influenza outbreaks 2010-2016: a systematic review of their distribution, avian species and virus subtype. Systematic reviews, 7(1), 17. Available at: https:/www.ncbi.nlm.nih.gov/pmc/a rticles/PMC5784696/\#. Accessed on the 15th March 2020.

Chioma, G., Afodu, O., Akinboye, O., Ndubuisi-Ogbonna, L., and Ogunnowo, D. (2017) Impact of access to credit on Poultry farmer's performance in Ikenne local government area of Ogun state, Nigeria. Available at: https://www.researchgate.net/public ation/319516161 Impact of access to_credit_on_Poultry_farmer's_per formance in I Ikenne_local_govern ment area of Ogun state Nigeria. Accessed $2 \overline{9}$ th March 2020.

Compassion in World Farming (2019) The Life of: Broiler Chickens. A v a i 1 a b 1 e a t : https://www.ciwf.org.uk/media/523 $5306 /$ The-life-of-Broiler- 
chickens.pdf. Accessed on the 15th March 2020.

Derbe, T., and Nachimuthu, K. (2016) Problems and prospects of poultry production in Amhara region, Ethiopia: A case analysis. Journal of Radix International Educational and Research Consortium Volume 5, Issue 5 (May, 2016) ISSN: $2250-$ 3994. Accessed on the 15th March 2020.

Dilger, A. C., Schroeder, A. L., and Moseley, W. M. (2016) Barriers to global implementation of current and development of new performanceenhancing technologies in meat production. Animal Frontiers, Volume 6, Issue 4, October 2016, Pages 50-55, Available at: https://doi.org/10.2527/af.20160044. Accessed on the 15th March 2020.

Donadeu, M., Nwankpa, N., AbelaRidder, B., and Dungu, B. (2019) Strategies to increase adoption of animal vaccines by smallholder farmers with focus on neglected diseases and marginalized populations. PLOS Neglected Tropical Diseases 13(3): e0007279. A v a i 1 a b l e a t : https://doi.org/10.1371/journal.pntd. 0007279. Accessed 29th March 2020.

Dumas, S. E., Lungu, L., Mulambya, N., Daka, W., McDonald, E., Steubing, E., Lewis, T., Backel, K., Jange, J., Lucio-Martinez, B., Lewis, D., and Travis, A. J. (2016). Sustainable smallholder poultry interventions to promote food security and social, agricultural, and ecological resilience in the Luangwa Valley, Zambia. Food security, 8(3), 507-520. Available at: https:/www.ncbi.nlm.nih.gov/pmc/a rticles/PMC5096737/. Accessed 29th March 2020.
FAO (2018) Africa Sustainable Livestock 2050: Livestock and livelihoods spotlight. NIGERIA. Cattle and Poultry Sectors. Available at: http://www.fao.org/3/CA2149EN/ca 2149en.pdf. Accessed on the 15th March 2020.

Ile, I. and Boadu, E. S. (2018) The paradox of youth empowerment: Exploring youth intervention programme in Ghana. Cogent Social Sciences (2018), 4: 1528709. Politics \& International Relations. Available at: https://doi.org/10.1080/23311886.20 18.1528709. Accessed on the 15 th March 2020.

Michael J. Darre (n. d.) The Importance of Poultry In Our Lives. Available at: http://animalscience.uconn.edu/exte $\mathrm{n}$ s i on/poultry - ex tension - 4 h_2_1874982872.pdf. Accessed 29th March 2020.

Nordhagen, S., and Klemm, R. (2018) Implementing small-scale poultry-for-nutrition projects: Successes and lessons learned. Maternal and Child Nutrition Volume 14, Issue S3 Supplement: Eggs: A High Potential Food for Improving Maternal and Child Nutrition October 2018 e12676. A v a i l a b l e a t : https://doi.org/10.1111/mcn.12676. Accessed 29th March 2020.

Nwandu, P. I., Ojogbane, J. A., Okoh, C., and Okechukwu, F. (2016) Poultry Production Business: A Means of Alleviating Poverty among Farmers. International Journal of Innovative Agriculture \& Biology Research 4(2):21-30, April-June, 2016 ISSN: 2354-2934. Available at: https://seahipaj.org/journals-ci/june$2016 /$ IJIABR/full/IJIABR-J-3 2016.pdf. Accessed 29th March 2020.

Nwaobiala, C. U., Nnamdi, U. S., and 
Ekumankama，O. O. (2018) Performance Analysis of National Directorate of Employment Graduate Poultry Farmers in Imo State, Nigeria. Nigeria Journal of Rural Sociology Vol. 18, No. 1, 2018. A v a i 1 a b 1 e a $\mathrm{t}$ : https://ageconsearch.umn.edu/recor d/287602/files/207.pdf. Accessed 29th March 2020.

Obasi, P. C. (2015) Evaluation of The Performance Of Agricultural Lending Schemes In Nigeria. European Journal of Agriculture and Forestry Research Vol.3, No.2, pp.52-63, May 2015 Published by European Centre for Research Training and Development UK. eISSN 2054-6327 (Online) Available at: http://www.eajournals.org/wpcontent/uploads/Evaluation-of-thePerformance-of-AgriculturalLending-Schemes-in-Nigeria.pdf. Accessed 29th March 2020.

Olumide-Oyaniyi, M. O., and Ajayi, A. O. (2019) Determinants of training needs of youths in broiler chicken production in Osun state, Nigeria and implications for extension workers. Journal of Agricultural Science 2 XXX 2019 103-116. Available at: http://dspace.emu.ee/xmlui/bitstrea $\mathrm{m} /$ handle/10492/5531/2019_2_olum i d e oyaniyi.pdffisequence $=1 \&$ isAllowed $=y$. Accessed 29th March 2020 .

Olugbenga, S. O., Olusegun A. O., Adebimpe O. A., and Akinbowale, T. T. (2015) Optimized Nutrients Diet Formulation of Broiler Poultry Rations in Nigeria Using Linear Programming. J Nutr Food Sci S14: 002. doi:10.4172/2155-9600.S14002 2. A v a i l a b l e a t : https://www.longdom.org/openaccess/optimized-nutrients-dietformulation-of-broiler-poultry- rations-in-nigeriausing-linearprogramming-2155-9600-S 14002.pdf. Accessed 29th March 2020.

Omiti, J. M., and Okuthe, S. O. (n. d.) An Overview of the Poultry Sector and Status of Highly Pathogenic Avian Influenza (HPAI) in Kenya. Africa/Indonesia Team Working Paper No. 4. Available at: https://assets.publishing.service.gov. uk/media/57a08ba340f0b652dd000 dd8/wp04_IFPRI.pdf. Accessed 29th March $20 \overline{20}$.

Onwualu, P. Z. (2011). Enhancing competiveness of the Nigerian Livestock Sub-sector through value addition on the industry, Paper Presented at the 16th annual conference of the Animal Science Association of Nigeria (ASAN) held at Kogi State University, Anyigba, Kogi State, Nigeria, 12th -15th September, 2011, pp 1. Accessed on the 15th March 2020.

Organisation for Economic Cooperation and Development (2020) Meat consumption (indicator). DOI: 10.1787/fa290fd0-en (Accessed on 15 March 2020) Available at: https://data.oecd.org/agroutput/meat -consumption.htm. Accessed on the 15th March 2020.

Panda, A. K., Kumar, A., Sahoo, B., Tanuja, S., and Swain, B. K. (eds.) (2016) Low Cost Feed Formulation for Rural Poultry Production. In book: Empowering Farmwomen through Livestock and Poultry Intervention. ICAR-Central Institute for Women in Agriculture. Available at:https://www.researchgate.net/publ ication/316667141_Low_Cost_Feed _Formulation_for_Rural_Poultry_Pr oduction. Accessed 29th March 2020.

Price, R. (2019) Youth employment needs in Nigeria. Institute of Development 


\section{Ajala, Ogunjimi, Famuwagun and Adebimpe}

Studies. Knowledge, evidence and learning for development (K4D). A v a i 1 a b 1 e a t : https://assets.publishing.service.gov. uk/media/5ddfdabbed915d015c5482 ee/691 Youth Employment in Nig eria.pdf. Accessed on the 15 th $\overline{\text { March }}$ 2020.

Richens, I. F., Hobson-West, P., Brennan, M. L., Lowton, R., Kaler, J., and Wapenaar, W. (2015) Farmers' perception of the role of veterinary surgeons in vaccination strategies on British dairy farms. Available at: https://www.ncbi.nlm.nih.gov/pubm ed/26530434. Accessed on the 29th March 2020.

Ricke, S. C. (eds.) (2017) Achieving sustainable production of poultry meat. Volume 1: Safety, Quality and Sustainability. Burleigh Dodds Series in Agricultural Science Number 13. A va i 1 a b 1 e a t : https://books.google.co.uk/booksfi Accessed on the 15th March 2020.

Rimi, N. A., Sultana, R., Muhsina, M., Uddin, B., Haider, N., Nahar, N., Zeidner, N., Sturm-Ramirez, K., and Luby, S. P. (2017).Biosecurity Conditions in Small Commercial Chicken Farms, Bangladesh 20112012. EcoHealth, 14(2), 244-258. A v a i 1 a b 1 e a t : https://doi.org/10.1007/s10393-0171224-2. Accessed on the 15th March 2020. Heise, H.,

Ritchie, H., and Roser, M. (2020) - "Meat and Dairy Production". Published online at OurWorldInData.org. Retrieved from: 'Available at: https://ourworldindata.org/meatproduction' [Online Resource]. Accessed on the 15th March 2020.

Science Communication Unit, University of the West of England, Bristol (2013). Science for Environment Policy In-depth Report: Sustainable food. European Commission DG Environment, November 2013. A va i $1 \mathrm{ab} 1 \mathrm{e}$ a t : https://ec.europa.eu/environment/ integration/research/newsalert/ pdf/sustainable_food_IR8 en.pdf. Accessed on the $\overline{1} 5$ th March $\overline{2} 020$.

Simonič, M., Dumičić, K., and Žmuk, B. (2015) Developing Marketing Strategy Of Poultry Meat Supply In Eu28 Countries: Multivariate Analysis Approach. Review of Innovation and Competitiveness Vol $2 \quad$ I s s u e 1 https://www.researchgate.net/public ation Accessed 29th March 2020.

Stiles, W. (2017) Poultry manure management. Available at: https://www.researchgate.net/ publication/321001761_Poultry_ma nure management/stats. Accessed on the 15th March 2020.

Tibi, K. N., \& Adaigho, D.O. (2015) Page Impact of Microfinance on SmallScale Poultry Production in Delta State, Nigeria. Journal of Agriculture and Veterinary Science (IOSR-JAVS) e-ISSN: 2319-2380, p-ISSN: 23192372. Volume 8, Issue 2 Ver. II (Feb. 2015), PP 01-07. Available at: http://www.iosrjournals.org/iosrjavs/papers/vol8-issue2/Version2/A08220107.pdf. Accessed 29th March 2020.

United States Department of Agriculture - USDA (2018). Chickens and Eggs. ISSN: 1948-9064 Available at: https://www.nass.usda.gov/Publicati ons/Todays_Reports/reports/ckeg12 18.pdf. Accessed on the 15th March 2020. Qualman, D. (2018) Earth's dominant bird: a look at 100 years of chicken production. Available at: https://www.darrinqualman.com/10 0 -years-chicken-production/. Accessed on the 15th March 2020.

United Nations Development 
Programme - UNDP (2020) Youth Empowerment. Available at: https://www.undp.org/content/undp/ en/home/ourwork/democraticg o v e r n a n c e - a n d $\mathrm{p}$ e a c e buildi n g/ y o u t h empowerment/. Accessed on the 15 th March 2020.

Wahyono, N. D. and Utami, M. M. D. (2018) A Review of the Poultry Meat Production Industry for Food Safety in Indonesia. January 2018 Journal of Physics Conference Series

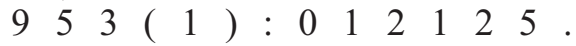
Availablehttps://www.researchgate.n et/publication/322953819_A_Revie w of the Poultry Meat Production Industry_for_Food_Safety_in_Ind onesia. Accessed 29th March 2020.
World Economic Forum (2019) Meat: the Future series Options for the Livestock Sector in Developing and Emerging Economies to 2030 and B e yond. Available at: http://www3.weforum.org/docs/Whi te_Paper_Livestock_Emerging $\% 20$ Economies.pdf. Accessed on the 15th March 2020.

Received: $20^{\text {th }}$ August, 2020 Accepted: $20^{\text {th }}$ December, 2021 